\title{
Cost Estimation and Comparison of Carbon Capture and Storage Technology with Wind Energy
}

\author{
ABDULLAH MENGAL*, KHANJI HARIJAN*, MOHAMMAD ASLAM UQAILI**, \\ NAYYAR HUSSAIN MIRJAT**, SYED MUSHTAQ AHMED SHAH*** \\ RECEIVED ON 15.03.2016 ACCEPTED ON 22.11.2016 \\ ABSTRACT
}

\begin{abstract}
The CCS (Carbon Capture and Storage) is one of the significant solutions to reduce $\mathrm{CO}_{2}$ emissions from fossil fuelled electricity generation plants and minimize the effect of global warming. Economic analysis of CCS technology is, therefore, essential for the feasibility appraisal towards $\mathrm{CO}_{2}$ reduction. In this paper LCOE (Levelized Cost of Electricity Generation) has been estimated with and without CCS technology for fossil fuel based power plants of Pakistan and also further compared with computed LCOE of WE (Wind Energy) based power plants of the Pakistan. The results of this study suggest that the electricity generation costs of the fossil fuel power plants increase more than $44 \%$ with CCS technology as compared to without CCS technology. The generation costs are also found to be $10 \%$ further on higher side when considering efficiency penalty owing to installation of CCS technology. In addition, the $\mathrm{CO}_{2}$ avoided costs from natural gas plant are found to be 40 and $10 \%$ higher than the local coal and imported coal plants respectively. As such, the electricity generation cost of 5.09 Rs/kWh from WE plants is found to be competitive even when fossil fuel based plants are without CCS technology, with lowest cost of 5.9 Rs./kWh of CCNG (Combined Cycle Natural Gas) plant. Based on analysis of results of this study and anticipated future development of efficient and cheap WE technologies, it is concluded that WE based electricity generation would be most appropriate option for $\mathrm{CO}_{2}$ reduction for Pakistan.
\end{abstract}

Key Words: Electricity Generation, Fossil Fuels, Wind Energy, Carbon Capture and Storage, Levelized Cost of Electricity Generation.

\section{INTRODUCTION}

$\mathrm{E}$ lectricity is essential for the social and economic development of any country. The rapidly increasing consumption of electricity due to the technological development has increased its demand. In order to meet this increasing demand different methods of generating electricity have been evolved. According to the estimates of the IEA (International Energy Agency) the electricity supplies about $35 \%$ of the total global energy needs and more than $82 \%$ of world energy needs are accomplished from fossil fuels [1]. It has been projected that the share of these fossil fuels will decline to $78 \%$ by 2040 due to the augmentation of the renewable energy 
technologies. Even with the heightened focus on renewables and nuclear power sources; it has been predicted that these fuels will dominate to other fuels for meeting the energy needs of the world in future $[2,3]$.

Power sector in Pakistan is dominated with thermal electricity generation. The total electricity generated in the country during financial year 2012-2013 was $96,122 \mathrm{GWh}$ of which the share of thermal electricity generation was $61,711 \mathrm{GWh}(64.2 \%)$, Hydro power plants generated 29,857GWh (31\%) and nuclear power plants supplied 4,553GWh (5\%). The Share of electricity generation from each source is shown in Fig. 1. However, one serious concern is that the electricity generated is far below the total installed capacity due to inappropriate fuel mix, inefficient power plants and lack of proper maintenance of power plants. The maximum peak demand in 2013 has been around $22,816 \mathrm{MW}$ while the power availability was only $17000 \mathrm{MW}$ which shows a shortfall of over $5000 \mathrm{MW}$. The increasing demand is further widening the supply-demand gap which is a huge challenge to the economy of the country $[4,5]$.

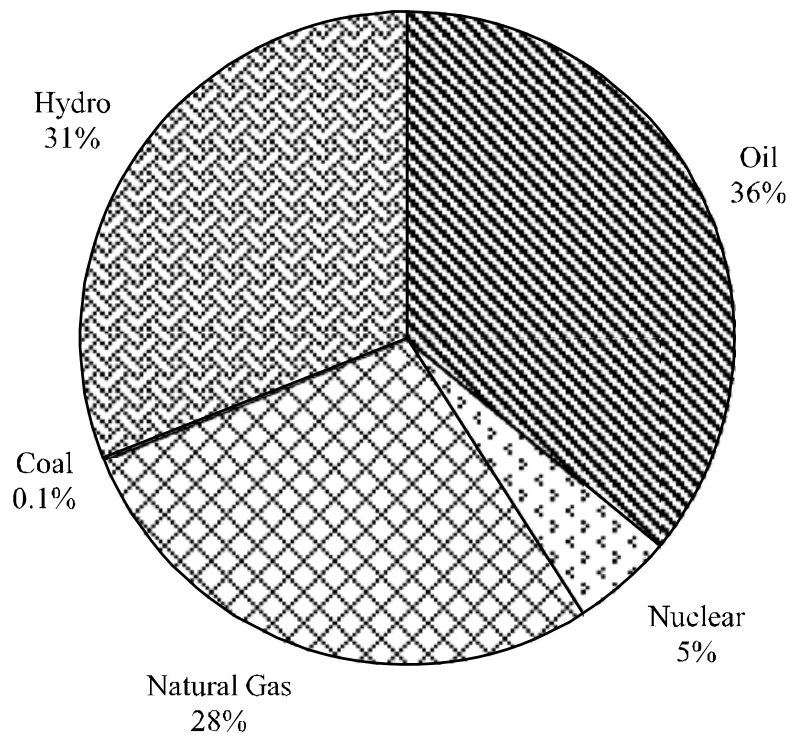

FIG. 1. SHARE OF ELECTRICITY GENERATION IN PAKISTAN DURING YEAR 2012-2013[4]
It is pertinent to mention that this increasing demand of electricity cannot be met from existing power generating plants. Further, generating electricity from costly imported fuel has also plunged country into the existing power crisis owing to enormous oil import bills and issues of circular debt thereof [6]. Dealing with these challenges, the present government announced a new power policy in 2013. The goal of this power policy was to build a power generation capacity that can meet Pakistan's energy needs in a sustainable way. To achieve this goal on long term basis government made a plan to ensure the generation of low-cost electricity from local coal (Thar), imported coal and natural gas [7].

The utilization of the fossil fuels for the power generation to meet increasing demand adversely causes growing emissions of $\mathrm{CO}_{2}$. Since the industrial revolution, the annual $\mathrm{CO}_{2}$ emissions from combustion of fossil fuels have considerably increased throughout the world. The major share of these emissions is from power sector where electricity is generated from oil, natural gas and coal. Coal power plants release more $\mathrm{CO}_{2}$ emissions than other fossil fuel power plants.

The $\mathrm{CO}_{2}$ emissions in Pakistan have increased from 14 million tons in 1960 to 163 million tons in 2011 as shown in Fig. 2. The main sources of these emissions are power generation, transportation and cement manufacturing industries, in which power generation contributes more than the other sources [8].The total $\mathrm{CO}_{2}$ emissions from power generation sources were 48 million tons in 2011 and it has been forecasted to reach about 155 million tons in 2030 under the new power policy in which a considerable share of electricity generation would be from local coal (Thar) and imported coal [9]. This increasing rate of $\mathrm{CO}_{2}$ emissions globally will leave negative impact on the environment such as global warming and climate change. 
It is also pertinent to mention that average global temperature of the earth's atmosphere is steadily increasing due to the increasing concentration of $\mathrm{CO}_{2}$ and other GHG (Greenhouse Gases) emissions in to the atmosphere [11]. These emissions are also the main contributor of climate change and other associated effects. These emissions trap the heat in the atmosphere reflected from the surface of the earth, increases the temperature of the atmosphere termed as global warming [12]. It has been observed by the climate scientists that the average temperature of the Earth has increased from $0.4-0.8^{\circ} \mathrm{C}$ over the last 100 years. The IPCC (Intergovernmental Panel on Climate Change) has forecasted that the average temperature of the Earth could increase between 1.4 and $5.8^{\circ} \mathrm{C}$ up to $2100[13,14]$.

This increasing temperature disturbs the natural system of atmosphere resulting extreme and unpredictable weather conditions, causing climate change which is adversely affecting human as well as other living organism on the earth. The excessive $\mathrm{CO}_{2}$ in the atmosphere is also absorbed by oceans making the sea water more acidic and less cordial for marine life.
In this context, Pakistan is severely vulnerable to climate change and it has lack of technical and financial capability to cope these adverse effects. The heavy floods of 2010 due to heavy monsoon rains killed about 2000 people and displaced twenty million from their homes in many regions of the country, also causing loss of about $\$ 45$ billion $[15,16]$. A severe heat wave socked the various parts of the country in June 2015, which caused more than 1200 deaths, particularly in Karachi. According to the report, most of the country have remained under the grip of a sever heat wave from $18^{\text {th }}-24^{\text {th }}$ June, with high temperatures recorded $49^{\circ} \mathrm{C}$ Celsius in southern parts of the country [17]. Further, chronic drought situation struck the Tharparkar District of Sindh province very badly in 2015 causing 315 infants death in two years suffering from malnutrition and water-borne diseases [18].

There are worldwide efforts to reduce $\mathrm{CO}_{2}$ emissions by improving energy efficiency and use of alternative energy sources. However, a rapid swapping from the fossil fuels will create difficulties to the global economy; since

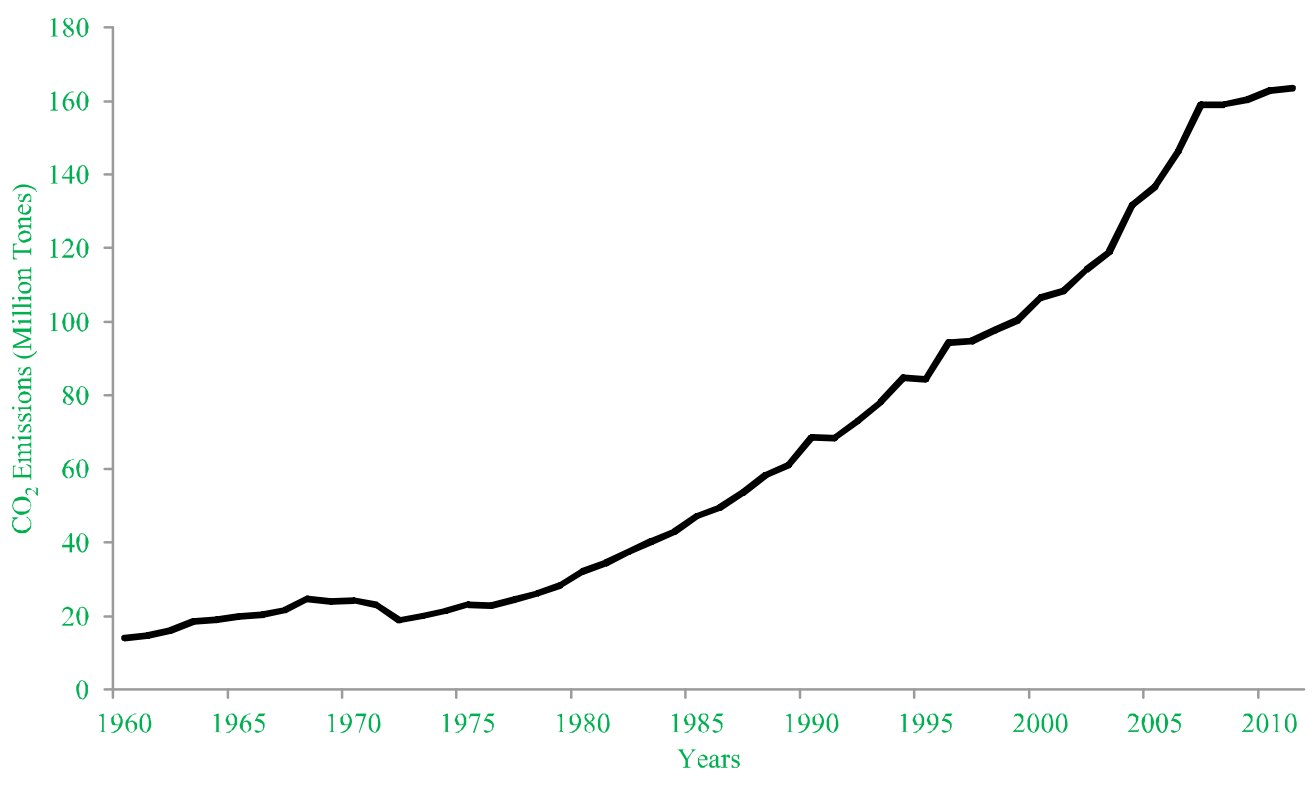

FIG. 2. $\mathrm{CO}_{2}$ EMISSIONS GROWTH IN PAKISTAN [10] 
alternative sources like renewables and nuclear cannot alone fulfill the world energy requirements at once. In this scenario the use of fossil fuels especially of coal in a sustainable manner is essential. In this context CCS is the significant solution to mitigate emissions caused by burning of fossil fuels. In this technology; $\mathrm{CO}_{2}$ in the flue gases which exhausts from the combustion of fossil fuels is separated, then compressed and transported to the places of stably stored, such as underground geological formations. $\mathrm{CO}_{2}$ capturing can be achieved by mainly using three methods from coal and other fossil fuel fired power plants like post-combustion, pre-combustion and oxy-combustion [19-21].

On the other hand, WE like other renewable technologies is clean and emission free energy source, playing a significant role for mitigation of $\mathrm{CO}_{2}$ emission. It is the rapidly growing electricity generation technology among the other renewable sources in the world with annual growth of more than $21 \%[22,23]$. Generation of electricity from wind turbines is cost competitive compared to conventional electricity generation technologies in wind potential areas. WE is widely available onshore as well as of off shore with great wind potential around the globe for power generation.

CCS is one of the various options being evaluated for $\mathrm{CO}_{2}$ reduction from the fossil fuel power plants but its economic viability assessment and cost comparison with other $\mathrm{CO}_{2}$ reduction options (renewable energies, energy efficiency measures) in particular Pakistan's context needs to be assessed appropriately. Although, currently in Pakistan, fossil fuel based power generation is mainly from oil, gas and nuclear fuels which are compared to coal release less overall emissions. However, future plans of Government of Pakistan clearly suggest that an estimated capacity of $40 \mathrm{GW}$ of electricity by 2035 shall be produced from coal plants. Even at present some of major coal based power plants (both on local and imported coal) each of 1320 MW capacity at Sahiwal, Karachi, Tharparkar and at Hub, Balochistan are under construction phase and likely to be commissioned by the end of year 2018 [9]. As such, the $\mathrm{CO}_{2}$ avoidance and the potential of CCS in Pakistan is explicitly evident in near future.

There are various studies undertaken globally by different researchers pertaining the performance, emission reduction and economic evaluation of CCS technology. Rubin and Zhai [24] have under taken a logical assessment of the effect of addition of CCS to the natural gas power plants. Lilliestam, et. al. [25] have compared the cost of CCS with CSP (Concentrating Solar Power) and also identified the risks and barriers of both of the technologies. Zhai and Rubin [26] have also estimated the plant-level cost and performance of the of dry and wet cooling PC (Pulverized Coal) power plants with and without CCS. A techno economical evaluation of ultra-super critical PC power plants and integrated gasification combine cycle power plants have been done by Tola and Pettinau in [21].

All of these researchers in their studies have estimated the costs and performances of various electricity generation sources without CCS and compared/evaluated the costs and performances with the generation sources when they are equipped with CCS. In this study LCOE by fossil fuel plants has been estimated without and with CCS technology in Pakistan's context. These costs are further compared with computed LCOE from WE base electricity generation to assess that which option of $\mathrm{CO}_{2}$ reduction is cost competitive.

\section{METHODOLOGY}

\subsection{Cost Estimation}

There are two main methods to estimate the cost of electricity generation from the power plants. These are: 


\subsubsection{Life Cycle Cost of Electricity Generation}

LCCOE (Life Cycle Cost of Electricity) Generation is an economic technique that involves the assessment of expected costs incurred during the whole life (from construction to the retirement and dispose off) of electricity generation plant. It also includes the costs incurred on research and design, construction, operation and maintenance, retirement and disposal. The total costs are discounted from the date of commissioning to the whole life of plant into present value. As such, present value can be calculated as $[27,28]$ :

$$
P V_{C}=\sum_{t=-L}^{n} C(t)(1+r)^{-1}
$$

Where $\mathrm{C}(\mathrm{t})$ is the cost occurred in year $\mathrm{t}, \mathrm{n}$ is the economic life of the plant, $\mathrm{L}$ is the construction period and $\mathrm{r}$ is the discount rate.

LCC of the power plants can be obtained by the summation of present values of all costs like $\mathrm{C}_{\mathrm{K}}$ (Capital Cost), $\mathrm{C}_{\mathrm{F}}$ (Fuel Cost), $\mathrm{C}_{\mathrm{O} \& \mathrm{M}}$ (Operating and Maintenance Cost) and $\mathrm{C}_{\mathrm{E}}$ (Externality Cost)

$\mathrm{LCC}=\mathrm{C}_{\mathrm{PVK}}+\mathrm{C}_{\mathrm{PVF}}+\mathrm{C}_{\mathrm{PVO} \& \mathrm{M}}+\mathrm{C}_{\mathrm{PVE}}$

Although LCCOE helps for decisions prior to accruing or developing assets related with the power project but one of the drawbacks is that it is not appropriate for the comparison of the costs of different electricity generation plants producing electricity from various sources having different life time [27].

\subsubsection{Levelized Cost of Electricity Generation}

LCOE is generally used to measure the electricity generation costs of power plants and compare these costs with other electricity generation plants over their economic life. It is the uniform revenue of each year to recover all the expenses over a specified life time of the electricity generation plants [20]. LCOE is basically the ratio of the total cost to build and operate a power plant throughout its life to the total output of the power plant in the same period represented in cost $/ \mathrm{kWh}$. Capital costs, fuel costs, O\&M (Operation and Maintenance) costs, financing costs and rate of utilization of the plant are the main inputs for its estimation which are converted to the PV (Present Value) cost. All of these costs mostly vary from region to region. Multiplying the PV by a factor called capital recovery factor transfer it into Levelized cost.

The LCOE is calculated using the equations given below [27]:

$$
\begin{aligned}
& \mathrm{LCOE}=\mathrm{C}_{\mathrm{k}}+\left[\sum_{\mathrm{t}=0}^{\mathrm{PL}} \frac{\mathrm{C}_{\mathrm{O} \& \mathrm{M}} \times\left(1+\mathrm{e}_{\text {O\&M }}\right)^{\mathrm{t}}}{(1+\mathrm{r})^{\mathrm{r}}}+\sum_{\mathrm{t}=0}^{\mathrm{PL}} \frac{\mathrm{C}_{\text {Fuel }} \times\left(1+\mathrm{e}_{\mathrm{Fuel}}\right)^{\mathrm{t}}}{(1+\mathrm{r})^{\mathrm{r}}}\right] \times \frac{\mathrm{r}(1+\mathrm{r})^{\mathrm{PL}}}{\mathrm{r}(1+\mathrm{r})^{\mathrm{PL}}-1} \\
& \mathrm{C}_{\mathrm{k}}=\frac{\mathrm{DR} \times \mathrm{TPC}(1+\mathrm{R})^{\mathrm{CL}}}{\mathrm{HY} \times \mathrm{CF}} \\
& \mathrm{C}_{\mathrm{O} \& \mathrm{M}}=\frac{\mathrm{FOM}}{\mathrm{HY} \times \mathrm{CF}} \\
& \mathrm{C}_{\text {Fuel }}=\mathrm{FC} \times \mathrm{HR}
\end{aligned}
$$

Where $\mathrm{C}_{\mathrm{k}}$ is Sum of the capital costs of plant, $\mathrm{C}_{\mathrm{O \& M}}$ is Operating and maintenance cost, $\mathrm{C}_{\mathrm{Fue}}$ is Fuel cost, TPC is Total plant cost $(\mathrm{Rs} / \mathrm{kW}), \mathrm{r}$ is Discount rate $(\%), \mathrm{CL}$ is Plant construction life (Years), $\mathrm{HY}$ is Hours per year, CF is Plant Capacity factor (\%), FOM is Fixed O\&M cost (Rs/ $\mathrm{kW}$ year), VOM is Variable O\&M cost ( $\mathrm{Rs} / \mathrm{kWh}), \mathrm{FC}$ is Fuel cost (Rs/MMBtu), $\mathrm{e}_{\mathrm{O \& M}}$ is Escalation rate of O\&M $\operatorname{cost}(\%), \mathrm{e}_{\text {Fuel }}$ is Escalation rate of fuel, $\mathrm{PL}$ is Plant life, and DR is Depreciation rate.

\subsubsection{Cost of $\mathrm{CO}_{2}$ Avoidance}

Finally, when electricity generation systems with CCS are considered for estimation of the economic costs then not only the LCOE is considered but the cost of avoiding the $\mathrm{CO}_{2}$ needs to be taken into account as well. Cost of $\mathrm{CO}_{2}$ 
avoided is the ratio of the difference in LCOEs to the differences of specific $\mathrm{CO}_{2}$ emissions having with $\mathrm{CCS}$ and without CCS $[29,30]$.

For electricity generation plants with $\mathrm{CCS}$ the $\mathrm{CO}_{2}$ avoided is calculated with help of following relationship [29].

$\mathrm{C}_{\mathrm{CO}_{2}}$ avoided $=\frac{\mathrm{LCOE}_{\text {capture }}-\mathrm{LCOE}_{\text {refrence }}}{\left(\frac{\mathrm{CO}_{2}}{\mathrm{kWh}}\right)_{\text {refrence }}-\left(\frac{\mathrm{CO}_{2}}{\mathrm{kWh}}\right)_{\text {capture }}}$

Where $\mathrm{LCOE}_{\text {capture }}$ is Plant with carbon capture and storage, $\mathrm{LCOE}_{\text {reference }}$ is Plant without carbon capture and storage, $\left(\mathrm{CO}_{2} / \mathrm{kWh}\right)_{\text {capture }}$ is $\mathrm{CO}_{2}$ emissions from plant with carbon capture and storage, $\left(\mathrm{CO}_{2} / \mathrm{kWh}\right)_{\text {reference }}$ is $\mathrm{CO}_{2}$ emissions from plant without carbon capture and storage

\subsection{Assumptions and Data}

The estimation of LCOE requires data pertaining the capital cost, operating and maintenance costs of power plants, construction period, life of the plant, plant capacity factor and fuel cost. The data related to these factors were taken from the literature [4,31]. Economic parameters used for cost estimation are discount rate, escalation rate of O\&M cost, and escalation of fuel cost. The values of these economic parameters were taken from the reports of Ministry of Finance, Government of Pakistan [32,33] and are presented in Table 1.

The construction period of the electricity generation plant plays an important role in the cost estimation because all expenses before the generation are part of the capital

TABLE1. LCOE ECONOMIC PARAMETERS [32.33]

\begin{tabular}{|c|c|}
\hline Factor & Value (\%) \\
\hline Discount rate & 8 \\
\hline Escalation of rate of O\&M & 2 \\
\hline Escalation of rate of fuel cost & 3 \\
\hline
\end{tabular}

cost and when the construction period increases then ultimately costs will increase as well. Further, the DR (Depreciation Rate) is calculated using the straight line method which is the ratio of difference between capital cost and salvage value to the total life of the power plant. Straight line depreciation method is applied here based on the assumption that power plant equipments depreciate uniformly over the entire life of the equipment. In the calculation of DR it was also assumed that the salvage would be zero at the retirement of the plant.

In order to compare the LCOE of different fuel sources for electricity generation with CCS and without CCS to the wind energy, four types of power plants were selected in this study. All the relevant data of electricity generation and cost of these plants are given in Tables 2-3.

The cost estimation with CCS only includes the cost of $\mathrm{CO}_{2}$ capturing while the costs pertaining to its compression, transportation and storage were not considered. Further, for the IGCC plants pre-combustion capturing process and for other plants post-combustion capturing process was considered. In the case of WE only onshore wind power generation has been considered.

Previous studies have signified that costs of electricity generation remarkably increases while overall efficiency of the plant decreases when it is equipped with CCS technology. The main reason for the same is that capital and operational costs of all components related to capturing unit are high and they consume more energy during the $\mathrm{CO}_{2}$ capturing process. As such, additional amount of fuel will be required when the generation plant consumes more energy due to CCS technology. High capital cost and additional fuel cost increases the LCOE of the plants having CCS technology [24,34]. In this study it was also assumed that overall efficiency reduction will remain about $10 \%$. 


\section{RESULTS AND DISCUSSIONS}

\subsection{Cost Estimation}

Using the data of Tables 1-3 pertaining the fossil fuel and wind power based electricity generation plants of Pakistan, the LCOE have been estimated with CCS and without CCS technology as shown in Figs 3-6. The estimated LCOE results without CSS technology are shown in Fig. 3. These results indicate that electricity generation from the IGCC power plants is found to be 9.8 $\mathrm{Rs} / \mathrm{kWh}$ which is the most expensive electricity generation option using local coal (lignite) as fuel. This is due to the

TABLE 2.COST, PERFORMANCE AND FUEL PRICES DATA FOR ELECTRICITY GENERATION PLANTS WITHOUT CCS [4,31]

\begin{tabular}{|c|c|c|c|c|c|}
\hline \multirow{2}{*}{ Cost Parameter } & \multicolumn{5}{|c|}{ Electricity Generation Sources Without CCS } \\
\hline & $\begin{array}{c}\text { Combined Cycle } \\
\text { Natural Gas } \\
\end{array}$ & $\begin{array}{l}\text { Local Coal } \\
\text { Combustion }\end{array}$ & $\begin{array}{c}\text { Imported Coal } \\
\text { Combustion }\end{array}$ & $\begin{array}{l}\text { Integrated Gasification } \\
\text { Combined Cycle }\end{array}$ & Wind Energy \\
\hline Plant capacity (MW) & 100 & 100 & 100 & 100 & 100 \\
\hline $\begin{array}{l}\text { Total plant cost } \\
\text { (Million Rs/MW) }\end{array}$ & 102.3 & 324.6 & 324.6 & 440 & 221.3 \\
\hline $\begin{array}{c}\text { Variable O\&M cost } \\
(\mathrm{Rs} / \mathrm{MWh})\end{array}$ & 327 & 447 & 447 & 722 & 0 \\
\hline $\begin{array}{c}\text { Fixed O\&M cost } \\
\text { (Rs/kW/year) }\end{array}$ & 1537 & 780 & 780 & 225 & 955 \\
\hline Fuel cost (Rs/MMBtu) & 488 & 282 & 454 & 282 & 0 \\
\hline Heat Rare (Btu/kWh) & 6430 & 8800 & 8800 & 8700 & 0 \\
\hline Plant life (years) & 30 & 30 & 30 & 20 & 25 \\
\hline Plant capacity Factor $(\%)$ & 87 & 82 & 82 & 80 & 33 \\
\hline Construction life (years) & 4 & 4 & 4 & 4 & 1 \\
\hline $\mathrm{CO}_{2}$ emission $\mathrm{kg} / \mathrm{MWh}$ & 0.35 & 1 & 0.81 & 0.72 & 0 \\
\hline
\end{tabular}

TABLE 3. COST, PERFORMANCE AND FUEL PRICES DATA FOR ELECTRICITY GENERATION PLANTS WITH CCS [4,31]

\begin{tabular}{|c|c|c|c|c|}
\hline \multirow{2}{*}{ Cost Parameter } & \multicolumn{4}{|c|}{ Electricity Generation Sources With CCS } \\
\cline { 2 - 5 } & $\begin{array}{c}\text { Combined Cycle } \\
\text { Natural Gas }\end{array}$ & $\begin{array}{c}\text { Local Coal } \\
\text { Combustion }\end{array}$ & $\begin{array}{c}\text { Imported Coal Combustion } \\
\text { Integrated Gasification } \\
\text { Combined Cycle }\end{array}$ \\
\hline Plant capacity (MW) & 100 & 100 & 100 & 100 \\
\hline Total plant cost (Million Rs /MW) & 209.5 & 522.7 & 522.7 & 659.9 \\
\hline Variable O\&M cost (Rs/MWh) & 678 & 951 & 851 & 845 \\
\hline Fixed O\&M cost (Rs/kW/year) & 3179 & 8053 & 454 & 7283 \\
\hline Fuel cost (Rs/MMBtu) & 488 & 282 & 12000 & 282 \\
\hline Heat Rare (Btu/kWh) & 7525 & 12000 & 30 & 10700 \\
\hline Plant life (years) & 30 & 30 & 82 & 20 \\
\hline Capacity Factor (\%) & 87 & 4 & 4 & 80 \\
\hline Construction life (years) & 4 & 0.15 & 0.12 & 4 \\
\hline CO emission kg/MWh & 0.05 & & 8.11 \\
\hline
\end{tabular}

Mehran University Research Journal of Engineering \& Technology, Volume 36, No. 2, April, 2017 [p-ISSN: 0254-7821, e-ISSN: 2413-7219] 
fact that both capital and operating costs of IGCC plants are higher as compared to the other power plants which make its generation more expensive. ICC power plants using the imported coal for electricity generation are next expensive to the IGGC power plants. The generation cost of these types of power plants is about $9.24 \mathrm{Rs} / \mathrm{kWh}$. The least cost electricity generation is $5.09 \mathrm{Rs} / \mathrm{kWh}$ from the WE power plants utilizing the energy of flowing winds. The reason of their least cost power generation is that the capital costs of wind power generation technology have significantly reduced since last many years on one hand and that being renewable source of energy they have no variable or fuel costs on other hand. The electricity generation cost of the NGCC plants based on domestic natural gas is $5.94 \mathrm{Rs} / \mathrm{kWh}$ which is relatively close to the WE plants. Finally, the costs of generating electricity from LCC based on the local coal (lignite) have been determined to be $7 \mathrm{Rs} / \mathrm{kWh}$.

Although the CCS is one of the important $\mathrm{CO}_{2}$ reduction technology but the main barrier for its development is very high capital and operating costs. The LCOE generation from fossil fueled power plants with CCS technology are shown in Fig. 4. The highest electricity generation cost of $14.09 \mathrm{Rs} / \mathrm{kWh}$ is found to be from ICC power plants with CCS technology utilizing imported coal (bituminous) as fuel which is owing to the fact that cost of imported coal is high as compared to the domestic coal used in other power plants. IGCC plants with CCS technology are less expensive than ICC power plants with CCS technology although having high capital cost since the fuel used in these power plants is local coal which is cheaper than the imported coal. Finally, it is determined that least cost generation with CCS technology is 8.12 $\mathrm{Rs} / \mathrm{kWh}$ from NGCC plants using domestic natural gas as fuel for electricity generation.

It is well established and discussed in previous sections of this paper that CCS technology requires additional energy consumption during capturing process which decreases the overall efficiency of the power plant known as the energy or efficiency penalty. This efficiency penalty is different for different electricity generation power plants. Due to the additional consumption of energy for

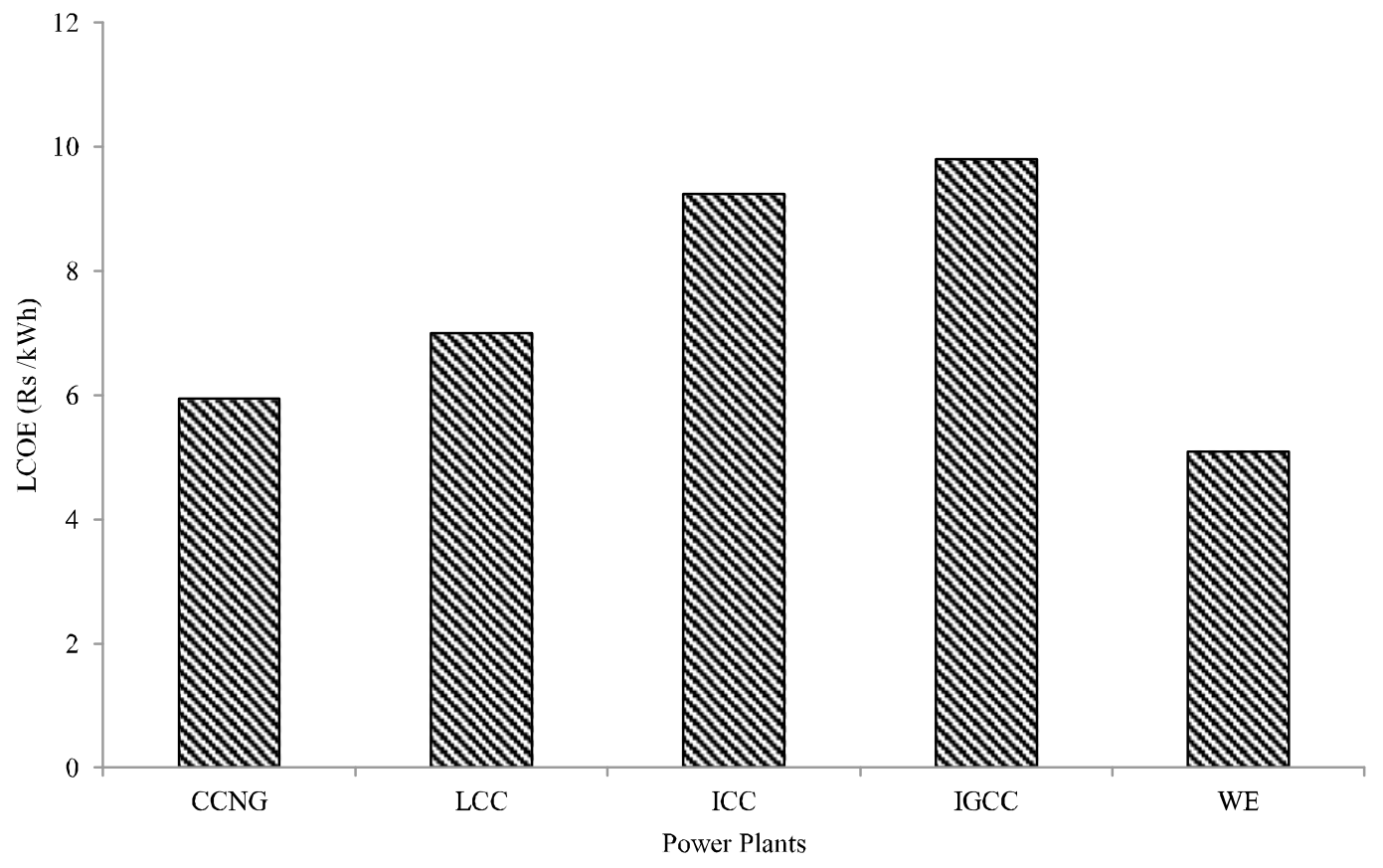

FIG. 3. LCOE OF POWER PLANTS WITHOUT CCS TECHNOLOGY

Mehran University Research Journal of Engineering \& Technology, Volume 36, No. 2, April, 2017 [p-ISSN: 0254-7821, e-ISSN: 2413-7219] 
CCS process it requires more fuel for plant to generate same amount of electricity as for it without CCS. Fuel cost is an important factor of the LCOE, as such; when it increases the overall economic cost will definitely increase $[19,21]$. In this study the energy penalty was assumed to be $10 \%$ for all generating sources, therefore, the fuel costs for all generating sources will increase by $10 \%$. The LCOE due to additional fuel costs is shown in Fig. 5.

\subsection{Cost Comparsion}

The comparison of estimated Levelized cost of electricity generation with CCS and without CCS technology for various power plants of this study are shown in Fig. 6. From the results it is obvious that LCOE significantly increase when electricity generating plants are considered with CCS technology than the plants without CCS technology. The increase in cost is around 44\% when electricity is generated by power plants having CCS capturing units. The highest generation cost of $15.5 \mathrm{Rs} /$ $\mathrm{kWh}$ is from the ICC power plants when the efficiency reduction due to the CCS technology is considered. The increase in cost is about $1.4 \mathrm{Rs} / \mathrm{kWh}$ due to efficiency reduction which is the highest in all electricity generation plants. The generation cost of CCNG plants only increases
$0.81 \mathrm{Rs} / \mathrm{kWh}$ due to efficiency reduction, therefore, its total cost is lowest than the other fossil fuel power plants. WE power plants are non-fossil fuel and emission free electricity generation plants, mitigation of $\mathrm{CO}_{2}$ is done without the CCS technology, as such; they are cost competitive in case of $\mathrm{CO}_{2}$ reduction.

Cost estimation of $\mathrm{CO}_{2}$ avoided is a useful standard criterion for the economic comparison of $\mathrm{CO}_{2}$ capture technology to the electricity generation plants without same. The calculated results of $\mathrm{CO}_{2}$ avoided costs from coal as well as natural gas electricity generation are presented in Table 4.

The $\mathrm{CO}_{2}$ avoided costs from natural gas are 40 and $10 \%$ higher than the local coal and imported coal respectively since the emission difference of reference plant to the capturing plant is less as compared to the coal wherein difference is more. The cost of $\mathrm{CO}_{2}$ avoided is also more in IGCC plants than the simple local coal based plants due to the high difference in the generation costs of reference and capturing plants. All the estimated electricity generation cost as well as $\mathrm{CO}_{2}$ avoided costs were also compared with the latest estimated costs in literature $[20,21,24,29]$ and were found very close to them.

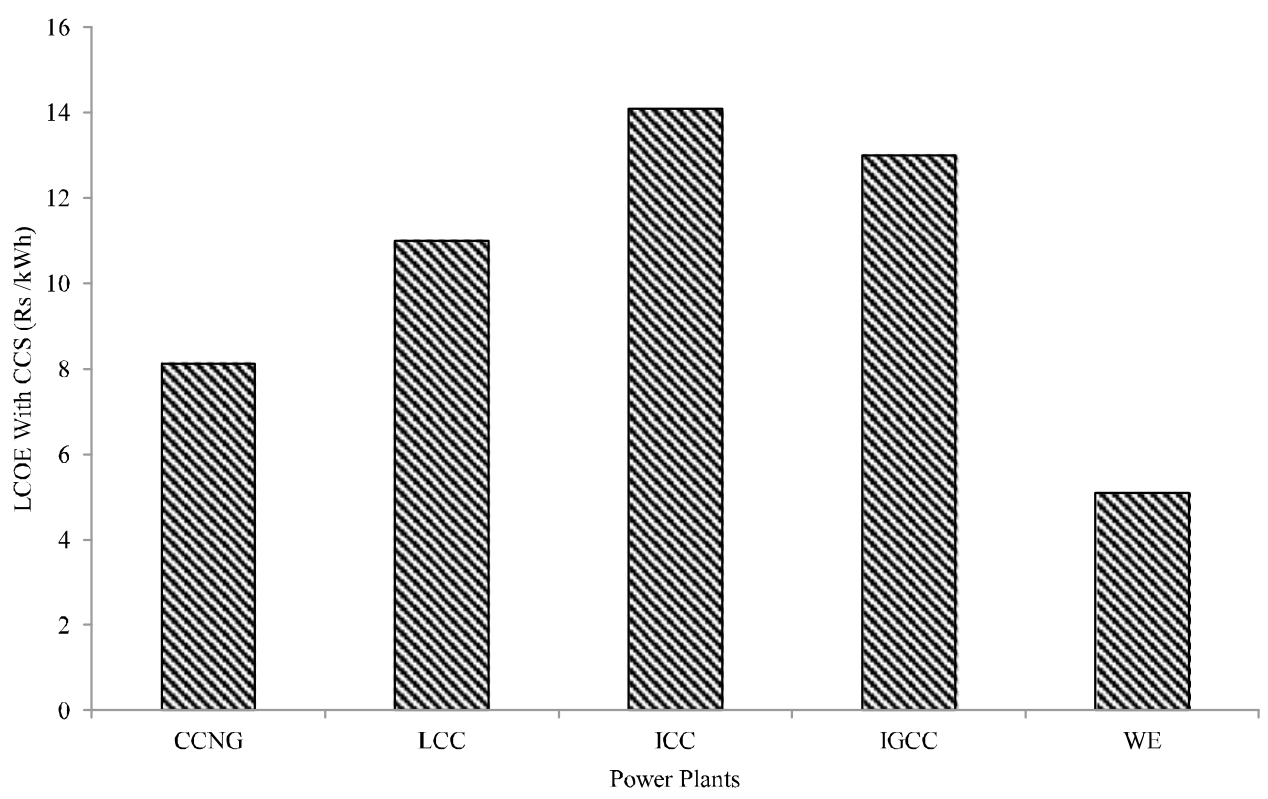

FIG. 4. LCOE OF POWER PLANTS WITH CCS TECHNOLOGY 


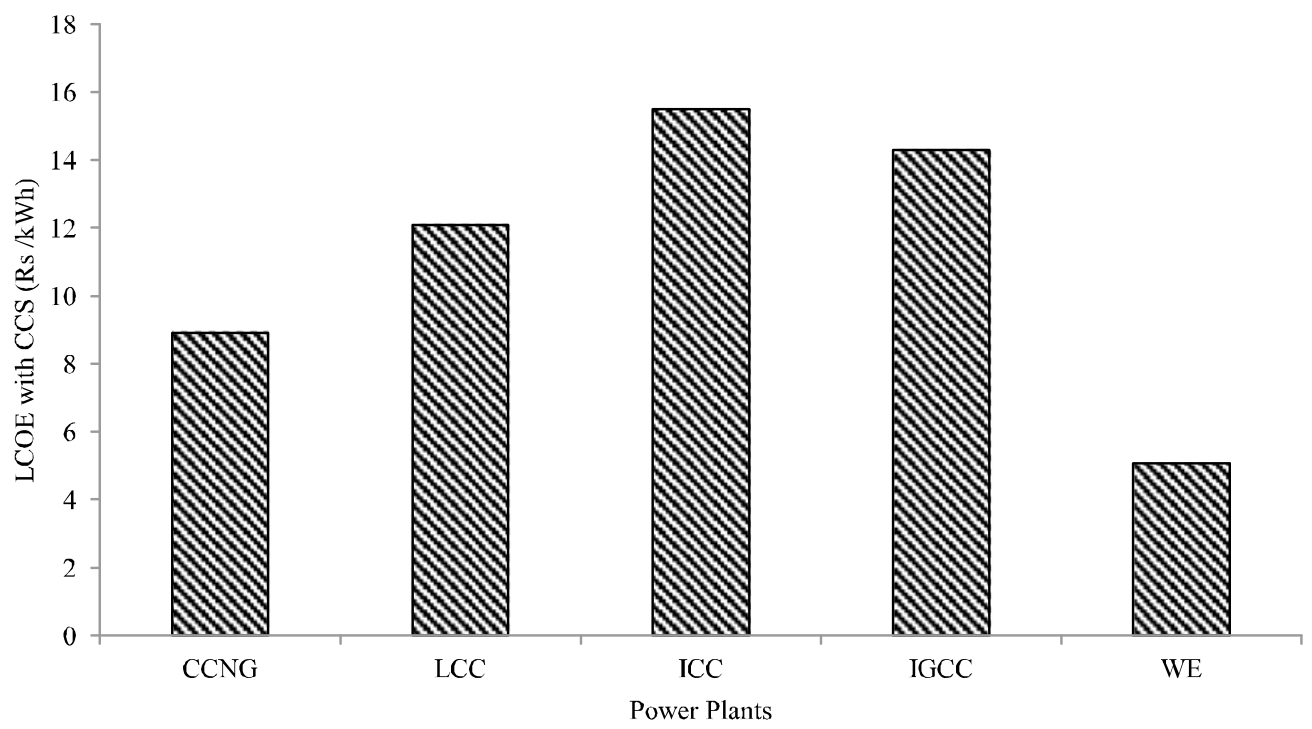

FIG. 5. LCOE OF POWER PLANTS WITH CCS TECHNOLOGY INCLUDINGEFFICIENCY PENALTY

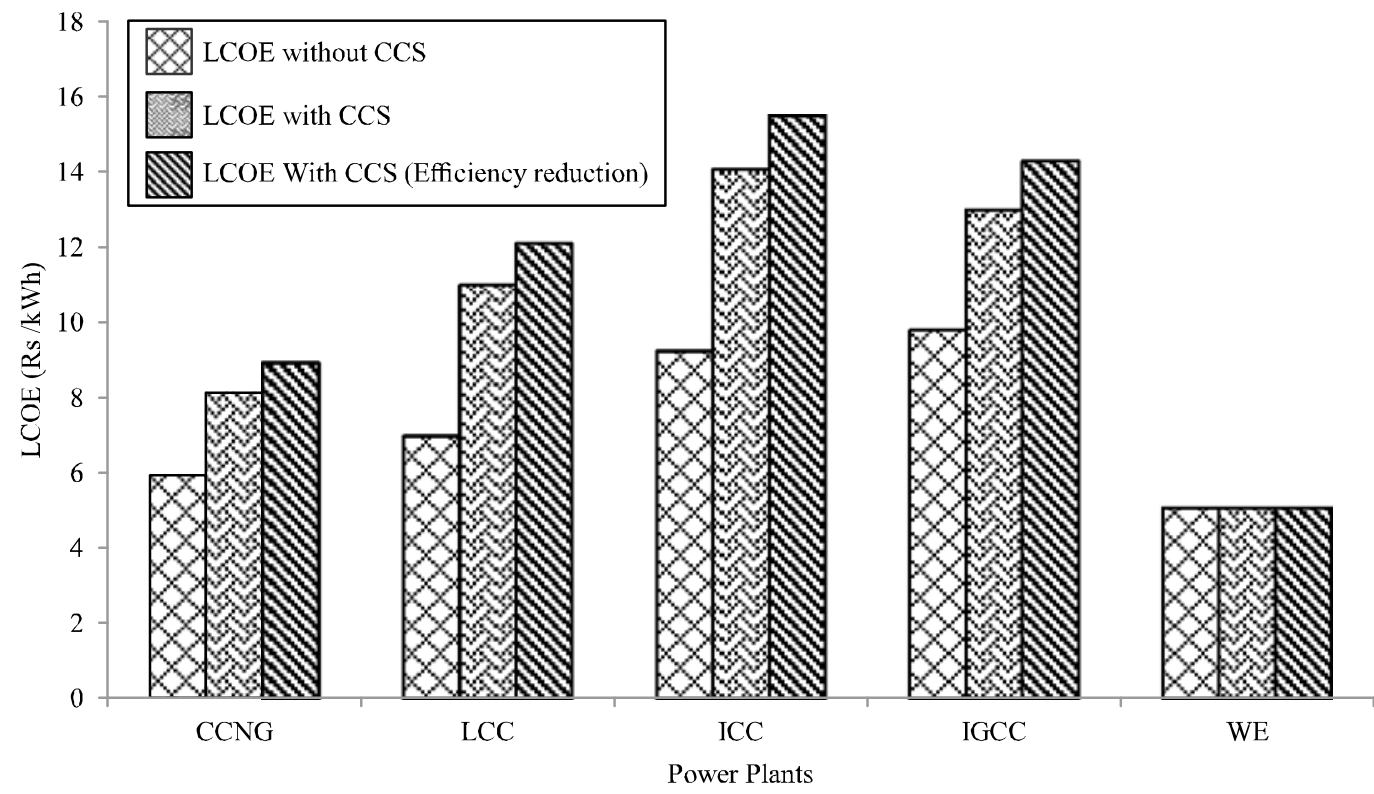

FIG. 6. LCOE COMPARISON OF POWER PLANTS

TABLE 4. $\mathrm{CO}_{2}$ AVOIDED COSTS FROM ELECTRICITY GENERATION PLANTS

\begin{tabular}{|c|c|c|c|}
\hline Fuel & $\begin{array}{c}\text { Electricity Generation } \\
\text { Technology }\end{array}$ & $\begin{array}{c}\mathrm{CO}_{2} \text { Capture } \\
\text { Technology }\end{array}$ & $\begin{array}{c}\text { CO2 Avoided Cost } \\
(\mathrm{Rs} / \mathrm{tCO}\end{array}$ \\
\hline Gas & Combined cycle & Post-combustion & 10000 \\
\hline Local coal & Pulverized fuel combustion & Post-combustion & 6000 \\
\hline Imported coal & Pulverized fuel combustion & Post-combustion & 9000 \\
\hline Local coal & Gasification Technology & Pre-combustion & 7300 \\
\hline
\end{tabular}

Mehran University Research Journal of Engineering \& Technology, Volume 36, No. 2, April, 2017 [p-ISSN: 0254-7821, e-ISSN: 2413-7219] 


\section{CONCLUSION}

CCS is one of the significant $\mathrm{CO}_{2}$ reduction technologies for sustainable electricity generation. This study estimated the LCOE and $\mathrm{CO}_{2}$ avoided costs of different electricity generation plants on the basis of updated capital, operation costs and considering relevant economic parameters for Pakistan. The estimated costs of electricity generation plants with CCS were compared with wind energy to analyze that which method of $\mathrm{CO}_{2}$ reduction is cost competitive. The results illustrate that the electricity generation costs of the fossil fuel power plants with CCS technology increase more than $44 \%$ than without same. The generation costs further increase by $10 \%$ when considering the efficiency penalty due to the application of CCS technology. Electricity generated from ICC power plants with imported coal (bituminous) as fuel, equipped with CCS technology is found to be $15.5 \mathrm{Rs} / \mathrm{kWh}$ which is the most expensive among all the electricity generation plants considered in this study, whereas natural gas plants with CCS having generation cost of $8.93 \mathrm{Rs} / \mathrm{kWh}$ being lowest economic costs of this technology. Further, the IGCC power plant using local coal (lignite) without CCS is found to be the most expensive source of electricity generation having generation cost of $9.8 \mathrm{Rs} / \mathrm{kWh}$. On the other hand, LCOE of the WE plants is found to be 5.09 $\mathrm{Rs} / \mathrm{kWh}$ which appeared as cost competitive compared to all fossil fuel sources of electricity generation even when CCS technology for the reduction of $\mathrm{CO}_{2}$ is not considered for fossil fuel plants. $\mathrm{CO}_{2}$ avoided costs from natural gas plant are found to be 40 and $10 \%$ higher than the local coal and imported coal respectively. This is owing to the fact that lesser amount of $\mathrm{CO}_{2}$ is avoided per unit of electricity generated during the combustion of natural gas. This study, as such, concludes that the CCS is very expensive option of $\mathrm{CO}_{2}$ reduction until it is fully mature and commercially and viably available.

\section{RECOMMENDATION}

It is recommended that renewables like WE, which is abundantly available in Pakistan, with progressively decreasing technological costs around the world is best option for $\mathrm{CO}_{2}$ reduction in Pakistan.

\section{ACKNOWLEDGEMENTS}

The authors acknowledge highly thanks to Mehran University of Engineering \& Technology, Jamshoro, and Balochistan University of Engineering \& Technology, Khuzdar, Pakistan, for their financial and technical support for completing this research work.

\section{REFERENCES}

[1] IEA, “World Energy Outlook", International Energy Agency, 2014.

[2] EIA, U., “Annual Energy Outlook 2014 with Projections to 2040", US Energy Information Administration, Washington, DC, 2014.

[3] Vellini, M., and Gambini, M., " $\mathrm{CO}_{2}$ Capture in Advanced Power Plants Fed by Coal and Equipped with OTM", International Journal of Greenhouse Gas Control, Volume 36, pp. 144-152, 2015.

[4] HDIP, "Pakistan Energy Yearbook 2013”, Hydrocarbon Development Institute of Pakistan, Ministry of Petroleum and Natural Resources, Government of Pakistan, 2013

[5] NTDC, "Electricity Demand Forecast Based on Multiple Regression Analysis", National Transmission and Distribution Company, Government of Pakistan, February, 2013.

[6] Mengal, A., Uqaili, M.A., Harijan, K., and Memon, A.G., "Competitiveness of Wind Power with the Conventional Thermal Power Plants Using Oil and Natural Gas as Fuel in Pakistan", Energy Procedia, Volume 52, pp. 59-67, 2014.

[7] GOP, "National Power Policy 2013", Government of Pakistan, 2013.

[8] WB, "The World Bank, $\mathrm{CO}_{2}$ Emissions in Pakistan", Available: http://data.worldbank.org/indicator/ EN.ATM.CO E.KT?locations $=$ PK\&year_high_desc $=$ false

[9] Gul, M., and Qureshi, W.A., "Long Term Electricity Demand Forecasting in Residential Sector of Pakistan", Power and Energy Society General Meeting, 2012.

[10] IEA, "CO $\mathrm{CO}_{2}$ Emissions from Fuel Combustion", Internal Energy Agency, 2014. 
[11] Hassan, I., Ghumman, A.R., and Hashmi, H.N., "Impact of Environmental Changes and Global Warming on Temperature in Pakistan", Mehran University Research Journal of Engineering \& Technology, Volume 30, pp. 1-14, Jamshoro, Pakistan, 2011.

[12] Farhat, A., "A Simple Approach to Estimate Soil Organic Carbon and Soil $\mathrm{CO}_{2}$ Emission", Mehran University Research Journal of Engineering \& Technology, Volume 32, Jamshoro, Pakisttan, 2013.

[13] Al-Qayim, K., Nimmo, W., and Pourkashanian, M., "Comparative Techno-Economic Assessment of Biomass and Coal with CCS Technologies in a Pulverized Combustion Power Plant in the United Kingdom", International Journal of Greenhouse Gas Control, Volume 43, pp. 82-92, 2015.

[14] IPCC, "Climate Change 2014: Synthesis Report. Contribution of Working Groups I, II and III to the Fifth Assessment Report of the Intergovernmental Panel on Climate Change", Intergovernmental Panel on Climate Change, 2014

[15] GOP, "National Climate Change Policy", Ministry of Climate Change, Government of Pakistan, Islamabad, Pakistan, 2012.

[16] Rasul, G., Mahmood, A., Sadiq, A., and Khan, S.I., "Vulnerability of the Indus Delta to Climate Change in Pakistan", Pakistan Journal of Meteorology, Volume 8, pp. 89-107, 2012.

[17] GOP, "Technical Report on Karachi Heat Wave", Ministry of Climate Change, Government of Pakistan, 2015 .

[18] DAWN, "Drought in Thar", Daily Dawn, Karachi, 2016.

[19] Davison, J., "Performance and Costs of Power Plants with Capture and Storage of $\mathrm{CO}_{2}$ ”, Energy, Volume 32, pp. 1163-1176, 2007.

[20] Finkenrath, M., "Carbon Dioxide Capture from Power Generation - Status of Cost and Performance", Chemical Engineering \& Technology, Volume 35, pp. 482-488, 2012.

[21] Tola, V., and Pettinau, A., "Power Generation Plants with Carbon Capture and Storage: A Techno-Economic Comparison between Coal Combustion and Gasification Technologies", Applied Energy, Volume 113, pp. 1461-1474, 2014.

[22] GRSR, "Global Renewable Status Report", 2014.
Harijan, K., Uqaili, M.A., Memon, M., and Mirza, U.K., "Forecasting the Diffusion of Wind Power in Pakistan", Energy, Volume 36, pp. 6068-6073, 2011.

[24] Rubin, E.S., and Zhai, H., "The Cost of Carbon Capture and Storage for Natural Gas Combined Cycle Power Plants", Environmental Science \& Technology, Volume 46, pp. 3076-3084, 2012.

[25] Lilliestam, J., Bielicki, J.M., and Patt, A.G., "Comparing Carbon Capture and Storage (CCS) with Concentrating Solar Power (CSP): Potentials, Costs, Risks, and Barriers", Energy Policy, Volume 47, pp. 447-455, 2012.

[26] Zhai, H., and Rubin, E.S., "Performance and Cost of Wet and Dry Cooling Systems for Pulverized Coal Power Plants with and Without Carbon Capture and Storage", Energy Policy, Volume 38, pp. 5653-5660, 2010.

[27] Mousavi, S.M., Ghanbarabadi, M.B., and Moghadam, N.B., "The Competitiveness of Wind Power Compared to Existing Methods of Electricity Generation in Iran", Energy Policy, Volume 42, pp. 651-656, 2012.

[28] Viebahn, P., Nitsch, J., Fischedick, M., Esken, A., Schüwer, D., Supersberger, N., Zuberbühler, U., and Edenhofer, O., "Comparison of Carbon Capture and Storage with Renewable Energy Technologies Regarding Structural, Economic, and Ecological Aspects in Germany”, International Journal of Greenhouse Gas Control, Volume 1, pp. 121-133, 2007.

[29] Hoffmann, B.S., and Szklo, A., "Integrated Gasification Combined Cycle and Carbon Capture: A Risky Option to Mitigate $\mathrm{CO}_{2}$ Emissions of Coal-Fired Power Plants", Applied Energy, Volume 88, pp. 3917-3929, 2011.

[30] Wang, S., Chen, Y., Zhong, P., Jia, L., and Zhu, Y., "Life Cycle Analysis of $\mathrm{CO}_{2}$ Control Technology: Comparison of Coal-Fired Power with Renewable Energy Power", Cleaner Combustion and Sustainable World, pp. 1291-1295. 2013.

[31] EIA, "Updated Capital Cost Estimates for Utility Scale Electricity Generating Plants", US Energy Information Administration, April, 2013.

[32] GOP, "Pakistan Economic Survey 2013-2014", Ministry of Finance, Finance Division, Government of Pakistan, 2014.

[33] TCEB, "Coal Tariff Determination", Thar Coal Energy Board, Government of Sindh, 2014 (Available: http:// sindhcoal.gos.pk/

[34] IEA, "Technology Roadmap, Carbon Capture and Storage", International Energy Agency, 2013. 